\title{
USE OF MEMBRANE EMULSION SPAN 80 AND TOPO IN URANIUM EXTRACTION AND STRIPPING
}

\author{
Kris Tri Basuki ${ }^{1}$, Nurimaniwathy ${ }^{2}$, Dian Puspita ${ }^{2}$, Bambang E.H.B ${ }^{2}$ \\ 1. Polytechnic Institute of Nuclear Technology - National Nuclear Energy Agency \\ Jalan Babarsari Kotak Pos 6101 YKBB Yogyakarta 55281, \\ 2. Center For Science and Accelerator Technology \\ National Nuclear Energy Agency \\ Jalan Babarsari Kotak Pos 6101 YKBB Yogyakarta 55281 \\ e-mail : kristri_basuki@batan.go.id
}

(Naskah diterima : 22-07-2016, Naskah direvisi: 12-08-2016, Naskah disetujui:

$$
\text { 26-08-2016) }
$$

\begin{abstract}
USE OF MEMBRANE EMULSION SPAN 80 AND TOPO IN URANIUM EXTRACTION AND STRIPPING. Membrane emulsion span 80 and TOPO used in uranium extraction and stripping has been done. The extraction was carried outby emulsion membrane $\mathrm{H}_{3} \mathrm{PO}_{4}$ in TOPO-Kerosene. The feed or external aqueous phase was uranium in $\mathrm{HNO}_{3}$. The emulgator span- 80 was used to obtain a stable emulsion membrane system. The influence factors were percentage of TOPOKerosene, time extraction, molarity of external aqueous phase and molarity of internal aqueous. After the emulsion membrane was formed, the extractionand stripping process was performed. The ratio volume feed : volume membrane phase equal to $1: 1$ and volume of $5 \%$ TOPOKerosene : Volume $3 \mathrm{M} \mathrm{H}_{3} \mathrm{PO}_{4}$ equal $1: 1$ were used. The relative good yield were obtained at concentration of TOPO in Kerosene and $3 \mathrm{M} \mathrm{H}_{3} \mathrm{PO}_{4}$ was $5 \%$, molarity of internal aqueous phase equal to $1 \mathrm{M}$, molarity of external aqueous phase $3 \mathrm{M} \mathrm{H}_{3} \mathrm{PO}_{4}$ and time extraction equalto 10 minutes with the speed of emulsification was $8000 \mathrm{rpm}$. At this condition the extraction efficiency of uranium obtained was $97.8 \%$, the stripping efficiency $52.56 \%$, and the total efficiency was $53.80 \%$.
\end{abstract}

Keywords: membrane emulsion, extraction, stripping, span 80, kerosene, uranium. 


\section{ABSTRAK}

PENGGUNAAN MEMBRAN EMULSI SPAN 80 DAN TOPO UNTUK EKSTRASI DAN STRIPPING URANIUM. Telah dilakukan penelitian membran emulsi span 80 dan TOPO yang digunakan untuk ekstraksi uranium. Extraksi dengan membran emulsi $\mathrm{H}_{3} \mathrm{PO}_{4}$ dalam TOPOKerosen. Larutan umpan untuk fasa air eksternal adalah uranium dalam asam nitrat. Untuk memperoleh sistem emulsi yang stabil dipakai emulgator Span 80. Parameter yang berpengaruh adalah persen TOPO-Kerosene, molaritas fasa air internal $\mathrm{H}_{3} \mathrm{PO}_{4}$, molaritas fasa air eksternal $\mathrm{HNO}_{3}$ dan waktu ekstraksi. Setelah diperoleh membran emulsi, kemudian dilakukan proses ekstraksi dan stripping, dengan rasio volume umpan : volume membran sebesar 1: 1; volume $5 \%$ TOPO-Kerose : volume $3 \mathrm{M} \mathrm{H}_{3} \mathrm{PO}_{4}$ sebesar 1 : 1 . Hasil relatif lebih baik diperoleh pada konsentrasi TOPO Kerosene: volume $3 \mathrm{M} \mathrm{H}_{3} \mathrm{PO}_{4}$ adalah $5 \%$, molaritas larutan fasa internal sebesar 1 $\mathrm{M}$, molaritas larutan fasa eksternal adalah $3 \mathrm{M} \mathrm{H}_{3} \mathrm{PO}_{4}$ dan waktu ekstraksi sebesar 10 menit dengan kecepatan emulsi 8000 rpm. Pada kondisi ini diperoleh effisiensi ekstraksi uranium 97,8 $\%$, efisiensi stripping $52,56 \%$ dan efisiensi total adalah 53,8 \%.

Kata Kunci : membran emulsi, ekstraksi, stripping, span 80, kerosen, uranium. 


\section{INTRODUCTION}

The extraction process so far was conducted trough several stages, namely, extraction scrubbing and stripping. Emulsion liquid membrane system are double emulsion drops. Two immiscible phases are separated by a third phase which is immiscible with the other two phases ${ }^{(1,2,3,4,5)}$. The liquid membrane sytems were classified in to three types ${ }^{[1,2]}$ :

1. Carried mediated mass transfer with reaction.

2. Mass transfer with reaction in the receiving phase.

3. Mass transfer without any reaction involved.

The field of liquid membrane technology is currenly undergoing arapid expansion of the areas of both research and industrial separation techniques. Emulsion liquid membranes can be manipulated to selectively separate a spesific solute from a mixture, and even to extract a solute against its concentration gradient ${ }^{[6,7,8,9,10]}$.

Uranium extraction and solvent extraction were used as purposes elements for each type of the membrane systems in the derivation of their mathematical models ${ }^{[11,12,13,14] \text {. }}$

Emulsion liquid membranes systems are comprised of three liquid phases. Two of these are miscible with each other but separated by a third phase (The membranes phase) which is immiscible with both. Mass is transferred from one of the miscible phase a cross the liquid membrane to the second miscible phase ${ }^{[15,16,17,18,19,20]}$. In General, liquid membranes can be held in porous structure or bounded on either side by two thin polymeric films. Emulsion (unsupported) liquid membranes are usually in the form of double emulsion drop. Ina Water/Oil/Water (W/O/W) system, immiscible is the oil phase, separating the two aqueouse phases, whilein an $\mathrm{O} / \mathrm{W} / \mathrm{O}$ system, the liquid membrane is the immiscible water phase which separates the two oil phases ${ }^{[8,13,19]}$.
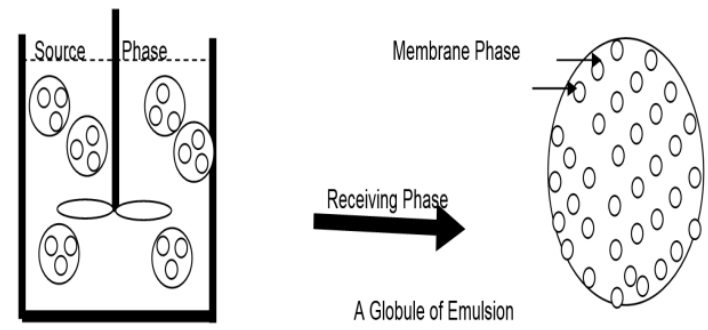

Figure 1. Configurations for emulsion unsupported

Figure 1 shows possible configurations emulsion (unsupported), and Figure 2 the configuration supported liquid membranes system.Globules is a granular of organic phase in the emulsion solution. The efectiveness of the emulsion liquid membrane process can be enhanced by utilization afacilited transport mechanism to maximize both the flux through the membrane phase, and capacity of the receiving phase for the diffusing species ${ }^{[1,2,11,13]}$.

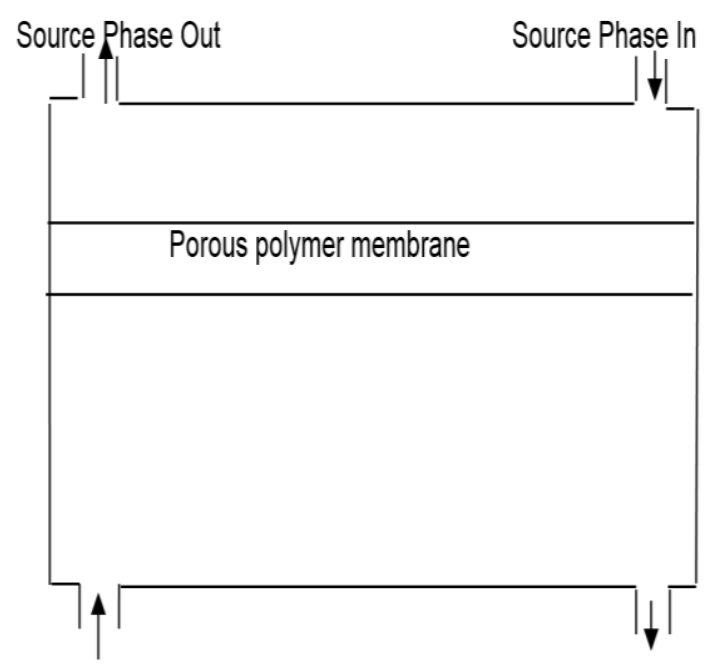

Figure 2. Configuration supported liquid membrane

Figure 3 shows a sequence of even in the preparation and operation for an W/ON emulsion liquid membrane system. The emulsion system are usually prepared by forming an emulsion from two immiscible phase by vigorously stirring at $5000-10000$ rpm. Then disperse this emulsion in conti- 
nuous phase (external phase) by low speed agitation. The liquid membrane phase which is separates the encapsulated droplets in the emulsion form the external continuous phase. In general, the internal phase droplets are very small, having diameter of 1 $10 \mu \mathrm{m}$, whereas the emulsion globules are usually about $0,1-2 \mathrm{~mm}$ in diameter. Surfactant and additives are normally included in the membrane. At the end of an extraction run, the emulsion and external phases can be separated, and reacted internal reagent phase can be recovered, if desired, by breaking the emulsion ${ }^{[1,2,4,5]}$.

The metalsare present in the external aqueous phase to be extracted by the extractors that exist in the organic phase by forming complex compounds. Complex compounds is further decomposed by internal water phase, therefore the extraction and re-extraction or stripping occurs simultaneously ${ }^{[11]}$ (Figure 4).

By emulsion membrane extraction method is expected to occur in saving extractant, because extractant not experiencing saturation and metals directly transfer-red to the internal water phase ${ }^{[11,12]}$. External aqueous phase is concentrated in a phase of uranium nitrate, the organic phase was extractant TOPO (Tri n-oktilphosphin oxide) in a kerosene diluent and internal water phase or the water phase stripping is phosphoric acid. TOPO is one of extractant that is often used for extraction using kerosene diluent ${ }^{[17]}$.

Emulsion system between organic phase and the internal water phase was produced using the span-80 emulsifier to form a water-in-oil emulsion systems ${ }^{[3]}$. The type of water-in-oil emulsion can be formed when used emulsifier which has a HLB value (Hidrophile Lipophile Balance) in range 4-12, while the HLB value of span- 80 was $4.3^{[1,2]}$.

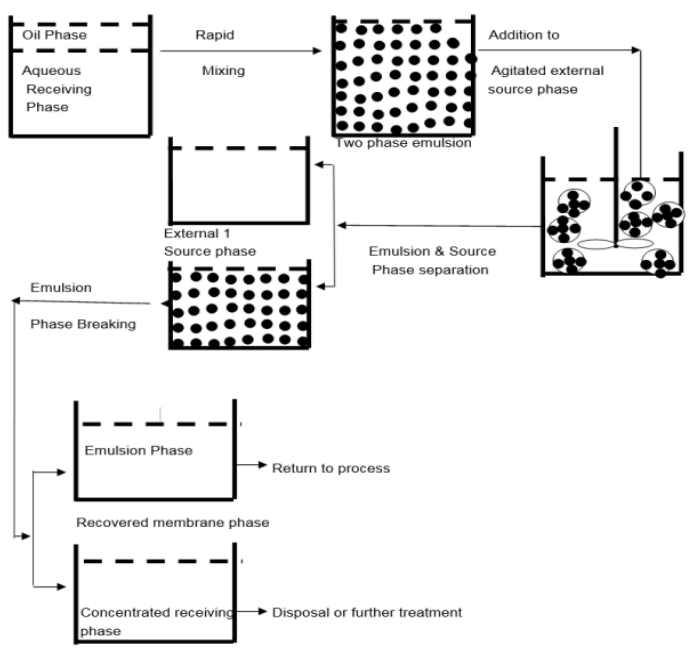

Figure 3. A Sequence of Events for an (W/O/W) Emulsion Liquid Membrane System.

The emulsion is said to be stable when the emulsion is not easily broken within a certain period. The longer the time the emulsion breaks, It is said to be more stable emulsion. The destruction caused by creaming and craking emulsion. Creaming occurs because the grain size is too large, so easily broken, whereas if the emulsion formation is not strong due to lack of emulsifier, resulting the emulsion becomes corrupted that called craking, because the grains are not uniform, small grains will be joined with larger grain become larger grain, so the emulsion became damage.

To determine the success of the process can be seen from the efficiency of extraction, stripping efficiency, and total efficiency.

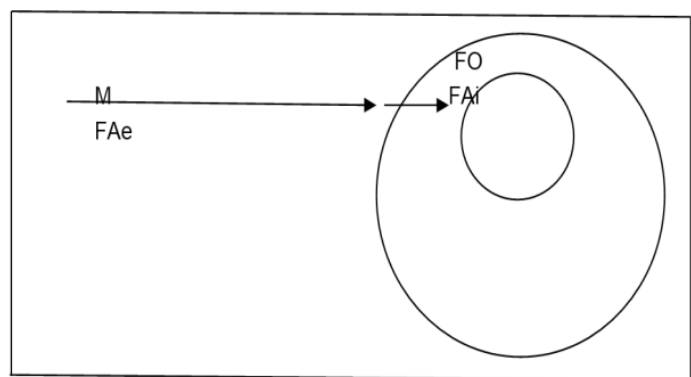

Figure 4. Metal transfer on the extraction of membrane emulsion. 
$\mathrm{M}=$ Metal

$\mathrm{FAe}=$ External phase aqueous

$\mathrm{FAi}=$ Internal phase aqueous

$\mathrm{FO}=$ Organic phase

Efficiency calculation formula according to the following equation:

$$
\begin{aligned}
& \text { Extraction Ef ficiency }=\frac{(\text { VFAeo.CFAeo })-(\text { VFAe.CFAe })}{(\text { FAeo CFAeo })} \times 100 \% \\
& \text { Total Efficiency }=\frac{(\text { VFAi. CFAi) }}{(\text { VFAeo.CFAeo })} \times 100 \%
\end{aligned}
$$

Stripping Efficiency $=\frac{(\text { VFAi. CFAeo })}{(\text { VFAeo.CFAeo })-(\text { VFAe.CFAe })} \times 100 \%$

Where

VFAeo $=$ The volume of the external aqueous phase before extraction (initial).

VFAe $=$ The volume of the external aqueous phase after extraction

VFAio $=$ The volume of the internal aqueous phase before extraction (initial)

VFAi $=$ The volume of the internal aqueous phase after extraction

CFAeo $=$ The concentration of the internal aqueous phase before extraction (initial)

CFAe $=$ The concentration of the external aqueous phase after extraction

CFAio $=$ The concentration of the internal aqueous phase before extraction (initial)

$\mathrm{CFAi}=$ The concentration of the internal aqueous phase after extraction.

\section{METHODOLOGY}

\section{a. Material:}

UNH from Merck, $\mathrm{HNO}_{3}, \mathrm{TOPO}$, Kerosene, Span-80.

\section{b. Tools :}

Heating and magnetic stirrer, stirrer ultra Turax, appliance glass and UV-VIS.

\section{c. Ways of working:}

1. Making the emulsion membrane (FM) and internal water phase (Fai)

$10 \mathrm{~mL}$ of $5 \%$ surfactan Span-80 were dissolved in $10 \mathrm{~mL}(5 \%$-Kerosen TOPO) as the organic phase plus $10 \mathrm{~mL}$ $\mathrm{H}_{3} \mathrm{PO}_{4} 3 \mathrm{M}$ as an internal phase (FAi). Ultra Turax was stirred for 15 minutes with a stirring speed varies from 2000-10000 rpm. The emulsion is formed as membrane phase (FM) is used for extraction of $20 \mathrm{mLthe}$ feed solution. The feed or external aqueous phase is $\mathrm{UNH} 1 \mathrm{M}$ in a solution of nitric acid was mixed with $20 \mathrm{~mL} F M$ for 10 minutes with stirring extraction at $150 \mathrm{rpm}$.

\section{The process of extracting and stripping}

UNH feed solution concentration (FAe) $1000 \mathrm{ppm}$ by volume of $10 \mathrm{~mL}$ plus $\mathrm{FM}=10 \mathrm{~mL}$ stirred for 10 minutes with a speed $150 \mathrm{rpm}$. The mixture was silenced for a moment and then separated with a separating funnel. FAe volume measured. FM heated briefly, the emulsion will break into FO and FAi. FO and FAi separated and measured its volume. FAe and FAi analyzed by UV-VIS.

This work was repeated to study the effects of \% TOPO-kerosene, then repeated for influence of variations the internal water phase molarity $\left(\mathrm{M} \mathrm{H}_{3} \mathrm{PO}_{4}\right)$, the feed molarity $\left(\mathrm{M} \mathrm{HNO}_{3}\right)$, and the stirring time.

Based on the experimental results analysis data calculation is then used to calculate the efficiency of extraction, stripping efficiency, and total efficiency uranium.

\section{RESULTS AND DISCUSSION}

Initial studies were done was to study the effect of stirring speed tool wear Ultra Turax on stability in the manufacture of membranes using $5 \%$ Span- 80 . The results can be shown in Table 1. 
Table 1. Effect of stirring speed on the membrane stability

\begin{tabular}{|c|c|c|}
\hline $\begin{array}{c}\text { Speed } \\
\text { (rpm) }\end{array}$ & $\begin{array}{c}\text { Time early } \\
\text { rupture } \\
\text { (hours) }\end{array}$ & $\begin{array}{c}\text { Time early } \\
\text { rupture with } \\
\text { heating } \\
\text { (minute) }\end{array}$ \\
\hline 2000 & 20 & 12 \\
\hline 4000 & 144 & 10 \\
\hline 6000 & 168 & 10 \\
\hline 8000 & 192 & 9 \\
\hline 10000 & 194 & 20 \\
\hline
\end{tabular}

In the manufacture of emulsion membrane selected stirring speed of 8000 rpm, because the membrane was relatively stable and recovered energy efficiency.

\section{a. Influence of percentage of TOPO- Kerosene}

(Ratio $\mathrm{FM}: \mathrm{FAe}=10 \mathrm{~mL}: 10 \mathrm{~mL}=$ $1: 1 ; \mathrm{FAi}=3 \mathrm{M} \mathrm{H}_{3} \mathrm{PO}_{4} ; \mathrm{Fae}=1 \mathrm{M} \mathrm{HNO}_{3}$; Stirring speed $=150 \mathrm{rpm}$; time of extraction : 15 minutes)

The membrane emulsion was a type of water-in-oil emulsion, ie $\mathrm{H}_{3} \mathrm{PO}_{4}$ in TOPOkerosene. This emulsion can be formed due to existing of span-80. The previous studies have investigated the parameters that form the emulsion becomes stable ${ }^{[1,2,10]}$. Relatively stable emulsion in the use of Span-80 as much as $5 \%$ by volume of the emulsion. Emulsion stability can be mea-sured by the amount of creaming figures expressed in the following equation:

$$
\begin{aligned}
& \triangle \text { VFAe } \quad \triangle \text { VFAi } 20 \\
& \triangle \text { VFAeo } \quad \triangle \text { VFAio } \\
& \triangle \mathrm{VFAe}=(\mathrm{VFAe}-\mathrm{VFAeo}) \\
& \triangle \mathrm{VFAi}=(\mathrm{VFAi}-\mathrm{VFAiO})
\end{aligned}
$$

Determination of \% TOPO is important in the mechanism of metal transfer in the internal water phase (FAi), because with increasing \% TOPO, then CFAi of $U$ growing, reaction with TOPO metal will be more better. To determine the effect of the displacement of uranium $(U)$ to the organic phase can be seen in the binding ability TOPO Uranium. At first, the uranium is at $\mathrm{FAe}$ in complex form solvated with water and nitrates. Due to the TOPO ligand $\mathrm{H}_{2} \mathrm{O}$ through the extraction process will be replaced by TOPO and form a neutral complex in the organic phase. The greater the concentration of TOPO, then the extraction efficiency will be even greater. This suggests that, the more uranium is extracted and form a neutral complex with TOPO on the membrane phase. Uranium is extracted, indicating more easily form a complex with TOPO. This can be shown in Figure 5.

In Figure 5 it can be seen that the concentration of TOPO affect the efficiency of uranium. The higher the concentration of TOPO then be increased efficiency. On the use of above $4 \%$ to $5 \%$ relative efficiency TOPO has been steady, due to the number of complex compounds of uranium greater with increasing TOPO, while a limited number of $\mathrm{H}_{3} \mathrm{PO}_{4}$ sripping the efficiency of uranium slightly decreased. $\mathrm{H}_{3} \mathrm{PO}_{4}$ ability to react is still quite strong, so the stripping efficiency is relatively the small.The effectiveness of the whole process of the extraction method of liquid emulsion mem-brane can be known by looking at total efficiency.

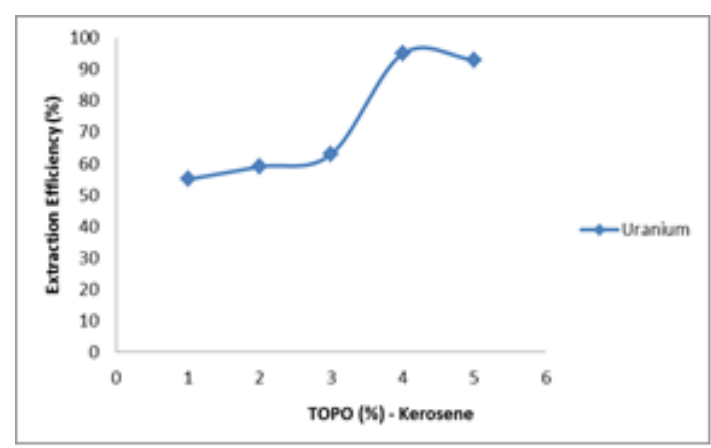

Figure 5 : Correlation of \% TOPO-Kerosene and extraction efficiency 


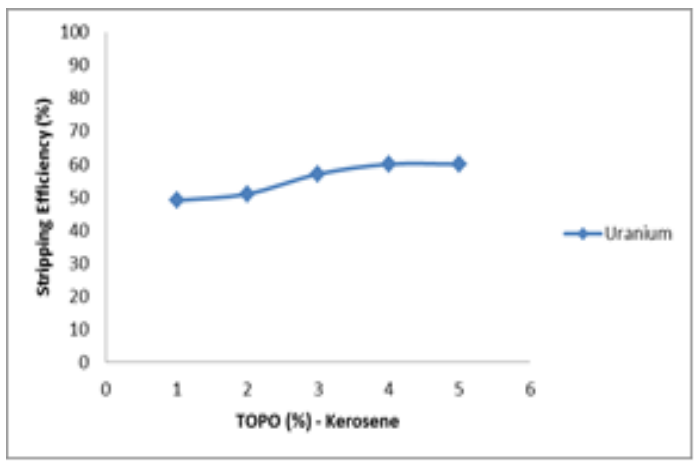

Figure 6. Correlation of \% TOPO-kerosene and stripping efficiency

To obtain a good extraction efficiency is measured by the value of the total uranium. From Figure 6 it can be seen that the relatively good results in the use of $5 \%$ TOPO.

Merging both extraction efficiency and stripping efficiency will be obtained total efficiency. Total metal efficiency in general has been rising with the growing percentage of TOPO. After calculations, the total efficiency of uranium as shown in Figure 7.

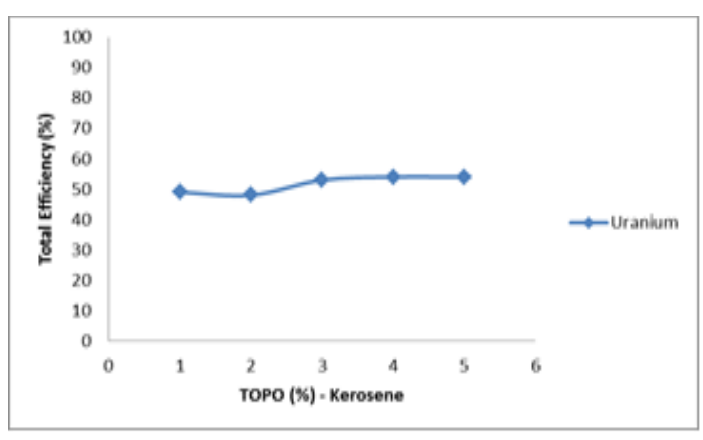

Figure 7. Correlation of \% TOPO-Kerosene and Total Efficiency.

\section{b. Effect of $\mathrm{FAi}\left(\mathrm{H}_{3} \mathrm{PO}_{4}\right)$ molarity}

(Ratio FM : $\mathrm{FAe}=10 \mathrm{~mL}: 10 \mathrm{~mL}=1$ $: 1$, TOPO-Kerosene $=5 \%, \mathrm{FAe}=\mathrm{HNO}_{3}$, stirring speed $=150 \mathrm{rpm}$, time of extraction $=$ 15 minute).

To find out how much uranium transfer to the organic phase it can be seen in Figure 8, FAi molarity relationship with the extraction efficiency, it appears that the extraction efficiency will increase with the increase of phosphoric acid to reach a round
2-3 $\mathrm{M} \mathrm{H}_{3} \mathrm{PO}_{4}$, but thereafter declined. The factors that influence are chemical the reactions and changes negative volume emulsion membrane systems. Increasing concentration of $\mathrm{H}_{3} \mathrm{PO}_{4}$, the causes osmotic pressure higher on $\mathrm{FAi}$, so more water coming into the FAi.

Effect of acidity FAi needs to be done to determine the most optimum acidity, to elaborate on the complex uranium into uranium that were concentration in FAi with ion complexes $\mathrm{PO}_{4}{ }^{-}$. Figure 8 . shows that the extraction efficiency rice with increasing of acidity FAi to use phosphoric acid $3 \mathrm{M}$.

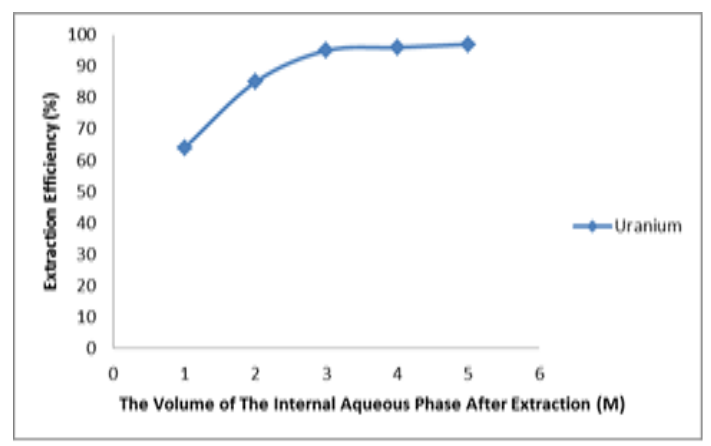

Figure 8. Correalation of the volume of Inter nal aqueous phase after extraction andextraction efficiency

Stripping efficiency grows with increasing of rice FAi acidity and relatively steady after molarity above of $3 \mathrm{M}$. With increasing of $\mathrm{H}_{3} \mathrm{PO}_{4}$ metal-TOPO decomposition reaction will be more perfect with the addition of $\mathrm{H}_{3} \mathrm{PO}_{4}$ concentration, and causing higher osmotic pressure on $\mathrm{FAi}$ causing water to pour into FAi. Basically complex compounds $\mathrm{UO}_{2}\left(\mathrm{NO}_{3}\right)_{2}$. 2 TOPO is very strong. Therefore, when reacted with $\mathrm{H}_{3} \mathrm{PO}_{4}-U$ difficult to unravel. Thus resulting in the stripping of $U$ is not too large.

Effect of molarity FAi against stripping efficiency can be seen in Figure 9, the complex TOPO- $\mathrm{H}_{3} \mathrm{PO}_{4}$ getting weaker so with the addition of $\mathrm{H}_{3} \mathrm{PO}_{4}$ molarity. Because the difference is not so great for the efficiency stripping of the process taken in $3 \mathrm{M}$ $\mathrm{H}_{3} \mathrm{PO}_{4}$ 
Merging both extraction efficiency and stripping efficiency will be obtained total efficiency. The total efficiency of the metal will rise with the swelling FAi acidition. The total efficiency of uranium as shown in Figure 10.

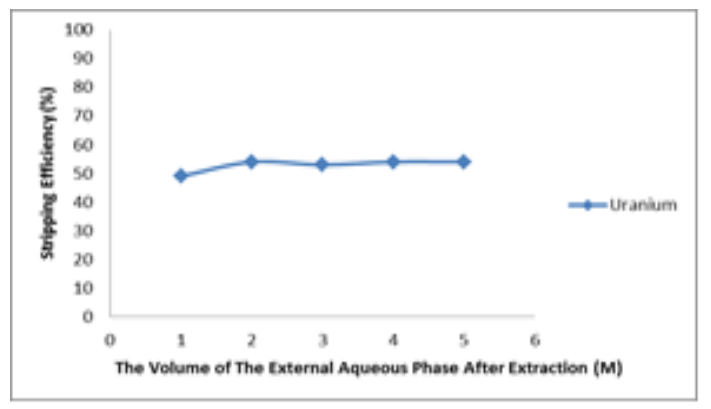

Figure 9. Correlation of the Volume of external aqueous phase after extraction and stripping extraction.

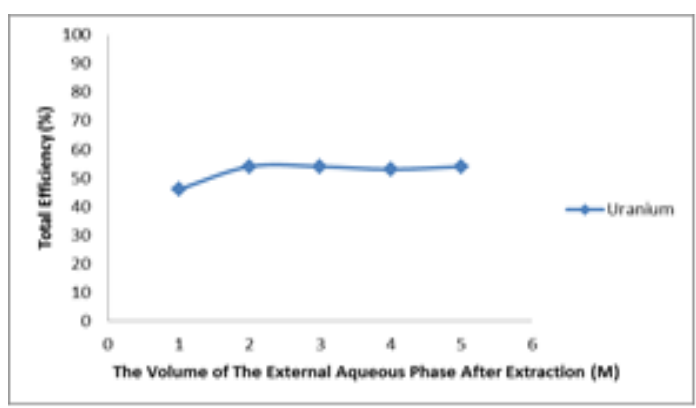

Figure 10. Correlation of the Volume of external aqueous phase after extractionand Total Efficiency (\%).

\section{c. Effect of $\mathrm{FAe}\left(\mathrm{HNO}_{3}\right)$ molarity}

(Ratio FM : $F A e=10 \mathrm{~mL}: \mathrm{mL}=1$ $: 1$, TOPO-Kerosene $=5 \%, F A i=3 \mathrm{M}$ $\mathrm{H}_{3} \mathrm{PO}_{4}$, stirring speed $=150 \mathrm{rpm}$, Time of Extraction $=15$ Minute) .

To find out how much metal transfer to the organic phase it can be seen in Figure 11 , the relationship with the FAE acidity extraction efficiency. At first the uranium is at $F A e$ in complex form solvated by water and nitrate. Due to the TOPO through the extraction process, $\mathrm{H}_{2} \mathrm{O}$ ligands will be replaced by TOPO and form a neutral complex in the organic phase. In figure 11 it appears that at the time the acidity of $0.5 \mathrm{M}$, the efficiency of extraction started rising and reached a maximum of $1 \mathrm{M}$, but thereafter declined. Affecting factors are chemical reactions and changes negative volume emulsion membrane systems.

Effect of molarity or acidity greatly to the extraction of uranium. The increase in the acidity of the extraction system is solvation, especially for extractant TOPO, causing TOPO will react with the acid solvent in this case $\mathrm{HNO}_{3}$.

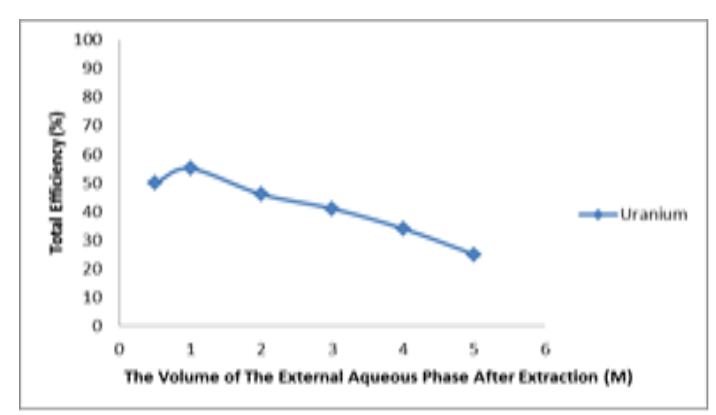

Figure 11. Correlation of the volume of external aqueous phase after extraction and extraction efficiency.

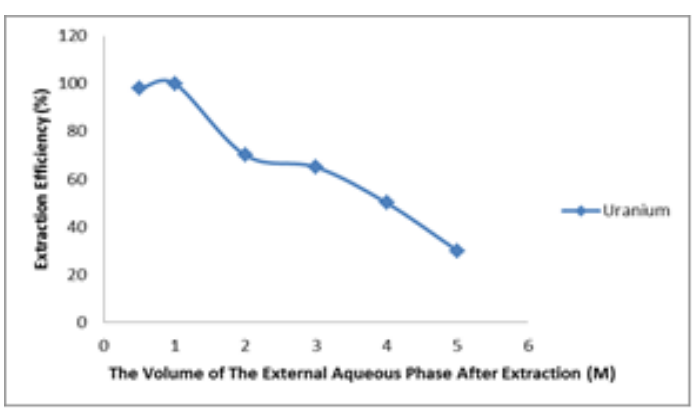

Figure 12. Correlation of the volume of external aqueous phase after extractionand stripping effici-ency (\%).

The fall in the efficiency of the extraction on the acidity after $1 \mathrm{M}$, as a result of the reaction between TOPO with $\mathrm{HNO}_{3}$ as a solvent feed. The factors that cause TOPO at high acidity are not able to extract the maximum uranium.

Metal extraction in the extraction system is influenced also by solvation of anions in the water phase. With the increase 
in acidity is an increase $\mathrm{HNO}_{3}$ or ion $\mathrm{NO}_{3}{ }^{-}$ excess in the solution.

The formation of complex compounds $\mathrm{UO}_{2}\left(\mathrm{NO}_{3}\right)_{2} 2 \mathrm{TOPO}$, cause is not readily biodegradable at the time of stripping, so the value could not be higher stripping efficiency. Uranium metal complex that forms in greater number, while the U-TOPO reduced, so that the efficiency of stripping decrease (see Figure 12). To determine the effectiveness of the whole process of extraction by the extraction method of liquid emulsion membrane can be determined at the total efficiency of the combination of both extraction efficiency and stripping efficiency. In figure 13 shown the relationship acidity FAe with total efficiency. Value at the optimum $1 \mathrm{M} \mathrm{HNO}_{3}$.

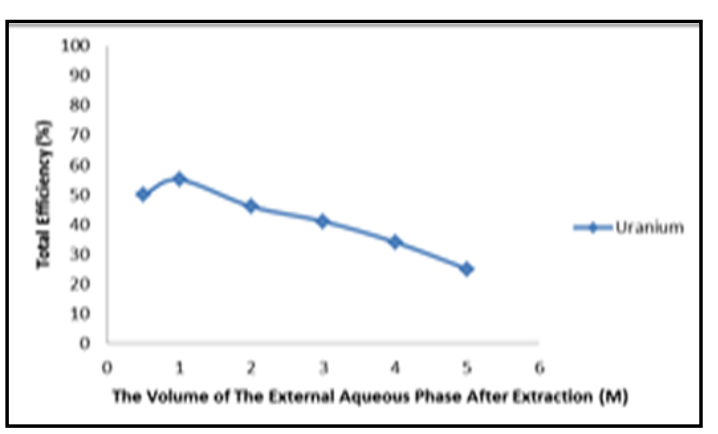

Figure 13. Correlation of the volume of the external aqueous phase after extraction andtotal efficiency (\%).

\section{d. Effect of extraction time}

(Ratio FM : FAe $=10 \mathrm{~mL}: 10 \mathrm{~mL}$ $=1: 1$, TOPO-Kerosene $=5 \%, F A i=3 \mathrm{M}$ $\mathrm{H}_{3} \mathrm{PO}_{4}$, stirring speed $=150 \mathrm{rpm}, \mathrm{FAe}=1 \mathrm{M}$ $\mathrm{HNO}_{3}$ ).

The extraction time is required to allow contact during the process of extraction and stripping lasts until it reaches equilibrium. The extraction process takes place between the reaction of uranium with TOPO. Stirring or extraction will form a new emulsion to emulsion membrane of a different size. Because there will be increase or decrease between the two phases of water, namely FAe and FAi.

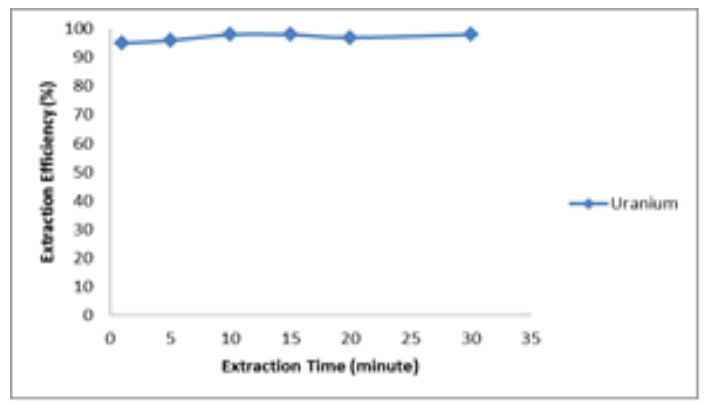

Figure 14. Correlation of extraction time (minute) and stripping efficiency

With the entry FAe into FAi accompanied by the transfer of uranium metal into TOPO as FO and forwarded FAi. U-TOPO extraction process and form a complex compound neutral Metal-TOPO pass through the membrane and decom-posed by a stripping agent into the FAi. Decomposition for their ion exchange reaction with $\mathrm{H}_{3} \mathrm{PO}_{4}$ where the complex will release reacting $\mathrm{UO}_{2}^{++}$with $\mathrm{PO}_{4}{ }^{3-}$.

The longer time of extraction, the extracted metals to form metal complexTOPO will be more and more. Figure 14 and Figure 16 is shown the relationship between the extraction efficiency, and extraction efficiency increases with the length of time of extraction, the optimum condition is achieved in 10 minutes, because of its efficiency relatively steady, the complex $\mathrm{UO}_{2}\left(\mathrm{NO}_{3}\right)_{2} 2$ TOPO. In figure 14 is shown that efficiency has been steadily after 10 minutes, because during that time already reached saturation point or achieve equilibrium.

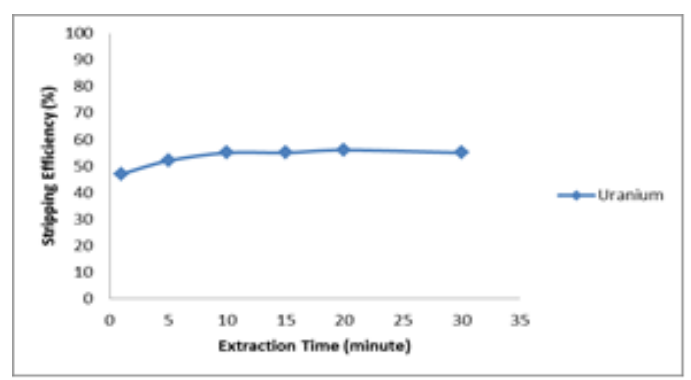

Figure 15. Correlation of extraction time (minute) and stripping efficiency 


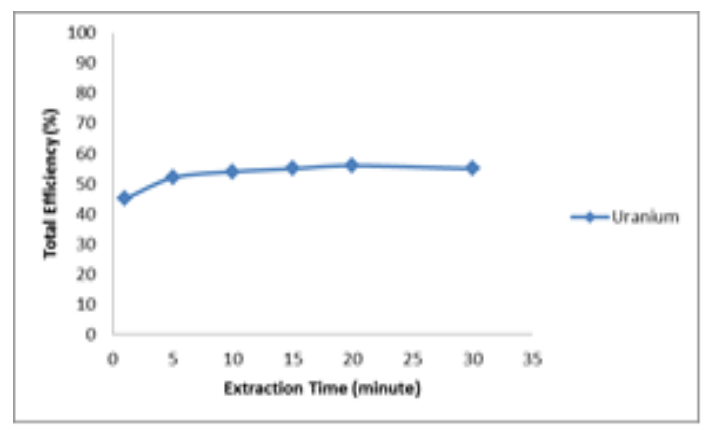

Figure 16. Correlation of extraction time (minute).

The combined efficiency of extraction and stripping efficiency will gene-rate total efficiency. In total efficiency, obtained by the graph in Figure 15 . The total efficiency reaches a maximum at 10 minutes and after that relatively constant. It showed that in 10 minutes 5\% TOPO capabilities have reached a saturation point in extraction of uranium clicking, so although the extraction time plus efficiency will not increase. Relative a good of extraction time at 10 minutes, which means that during time the uranium at feeds extraction by TOPO formed a neutral complex. In that interval $\mathrm{H}_{3} \mathrm{PO}_{4}$ who are at $\mathrm{FAi}$ able to download all the decomposition of metal-ligand complexes TOPO formed on the membrane phase during the extraction process. So as much as the amount of $\mathrm{H}_{3} \mathrm{PO}_{4}$ complex U-TOPO. Figure 16 shows that extraction time versus total extraction, the time achieved is 10 minutes.

\section{CONCLUSION}

Therelative good result of this research is the extraction volume of $10 \mathrm{~mL}$ feed solution in an atmosphere of $1 \mathrm{M}$ $\mathrm{HNO}$, membrane extraction with $10 \mathrm{~mL}$ of $5 \%$ TOPO-kerosene and $\mathrm{H}_{3} \mathrm{PO}_{4} 3 \mathrm{M}$ for 10 minutes with a stirring speed at the time of extraction of $150 \mathrm{rpm}$, speed manufacture of membranes $8000 \mathrm{rpm}$ and the use of span80 equal to $5 \%$.

In this state obtained uranium extraction efficiencyequal to $97.80 \%$,
$52.56 \%$ of stripping efficiency and total efficiency equal to $53.80 \%$.

\section{ACKNOWLEDGEMENTS}

The author would like to thank to Sudibyo, Suyanti, Suprihati, Imam Prayogo, Sudarso and Trimohadi who have helped this work in the laboratory of the Center for Technology Accelerator and process materials.

\section{REFERENCE}

[1] Abou-Nemeh and Van Petegen, A. P., (1992),"Sorbitan Monooleat (Span 80) Decomposition during Membrane Ageing. A. Kinetic Study“, Membrane Sci.,m 74, 9-17.

[2] Abou-Nemeh and Van Petegen, A.P., (1993), "Membrane Recycling in Liquid Surfactan Membrane Process", Ind. Eng. Chem. Res.,32, 143-147.

[3] Bogemen, D., Neplenbroug, A. M., and Smolders., (2002), "Nitrate Removal Using Supported Liquid Membrane : Transport Mechanism“, J. Membrane Sci. 67, 107-119.

[4] Bartsch, R. A. And Way, J. D., (2006), "Chemical Separation with Liquid Membrane", Symposium Series 642, pp. 91-93, 361-372, 181-193, American Chemical Society, Cali-fornia.

[5] Brecevic, L. And Kralj, D., (2008), "Precipitation of Some Slightly Soluble Salts Using Emulsion Liquid Membranes ", CCACAA, 4, 1049 -1060.

[6] Hartmann, D., (2009), "Extraction De L'Uranium Des Solution, Delixivation, En Tas Par des Membrane Liquid Emulsionnnes ", These, Ecole Centrale Paris, Paris.

[7] Sayworth, H.C. and Burn, W. A., (2003), "Extraction of Uranium from Wet Process Phosphoric Acid by 
Liquid Membrane“, Sep. Sci. Technol., $18,493-521$.

[8] Hirai T., Hashimoto, T., Tsuboi, I., Hino A., and Komasawa, I., (2005), "Extraction and Separation of Molibdenum and Vanadium Using Bis (2ethylhexyl) Monothiophosphoric Acid and Bis (2-ethylhexyl) Phos-phoric Acid“., J. Chem. Eng. Jap., 28, 85 90.

[9] Hirai., Nishihihama, S., and Komasawa, I., (2009), "Mechanism of Photoreductive Stripping Of Iron (III) In a Liquid-Liquid Extraction System and Its Application for Hydrometallurgical Prcocess", Ind. Eng. Chem. Res., 38, 4850 - 4856.

[10] Jing-Qing, S., Wei-Ping, Y., Yong-Xin, Z., and Li-Jun, Y., 2006., (2006), "Extraction of Alanine Using Emulsion Liquid Membranes Featuring a cationic Carrier", J. Membranes Sci., 120, $45-53$.

[11] Jyh-Herng, C., Yin-Yun, K., and ChiaHung, L., (2013), "Selective Separation of Vanadium from Molibdenum Using $\mathrm{D}_{2}$ EHPA-Immo-bilized Amberlite XAD-4 Resin“, Sep. Sci. Technol., $38,3827-3852$.

[12] Broberg, L., Lewin, I and Warshawsky, A., (2002), "Membrane Extraction of Silver by $\mathrm{DI}(2 e$ thylhexyl)Dithiophosphoric Acid ", J. Membrane Sci., 70, 31-39.

[13] Cahn, R. P. And Li, N. N., (2004), "Separation and Phenol From Waste water By the Liquid Membrane Technique" Sep. Sci., 9, 505.
[14] Dhadke, P. M. And Singh, R. K., (2012), "Extraction and Separation Of Titanium (IV) with $D_{2}$ EHPA and PC88A from aqueous perchloric acid solution“ ., J. Serb. Che. Soc., 67, 507 -521 .

[15] Casnaval, D., Oniscu, C., and Galaction, A. I. (2010), "Study on Reactive Extraction of Erychromycin", Roum. Biotechnol. Lett., 5, 439 - 447.

[16] Casamata, G., Chavarie, and Angelino, H., (2008), "Permeation Rate of Hydrocarbons through Water Membranes in an O/W/O Emulsion Sytem " AIChE. J., 24, 945.

[17] Korfan, S., Shino, O., Wahaud, A., and Dahdouh, A., (2010), "Stripping of Uranium From $D_{2}$ EHPA/TOPO Solvent By Ammonium Carbonat Solutions“, Chem. Eng., 44, 123 132.

[18] Nakano, K., Kato, S., Noritomi H., And Nagahama, K., (2007), "Extraction of Eicosapentaenoic Acid Ethyl Ester from Model Media Using $\mathrm{Ag}(\mathrm{I})$ containing O/W/O-Type Emulsion Liquid Membranes“, J. Membranes Sci., 136, 127 - 139.

[19] Sun, D., Duan, X., Li, W., and Zhou, D., (2008), "Demulsification of WaterIn-Oil Emulsion by Using Porous Glass Membrane“, J. Membrane Sci., $146,65-72$.

[20] Wang, C., Liu, D., and Zhang, J., 2011 "Solvent Extraction of Indium (III) and Iron (III) from Sulfuric Acid Media by Mixtures of D2EHPA and Cyanex 92", Sep. Purif. Technol., 61, $75-89$. 
